\title{
Article
}

\section{Rethinking Transnationalism in the Global World: Contested State, Society, Border, and the People in between}

Cheng, Isabelle and Momesso, Lara

Available at http://clok.uclan.ac.uk/28651/

Cheng, Isabelle and Momesso, Lara ORCID: 0000-0002-4042-9384 (2019) Rethinking Transnationalism in the Global World: Contested State, Society, Border, and the People in between. International Migration, 57 (4). pp. 197201. ISSN 0020-7985

It is advisable to refer to the publisher's version if you intend to cite from the work. http://dx.doi.org/10.1111/imig.12594

For more information about UCLan's research in this area go to http://www.uclan.ac.uk/researchgroups/ and search for <name of research Group>.

For information about Research generally at UCLan please go to http://www.uclan.ac.uk/research/

All outputs in CLoK are protected by Intellectual Property Rights law, including Copyright law. Copyright, IPR and Moral Rights for the works on this site are retained by the individual authors and/or other copyright owners. Terms and conditions for use of this material are defined in the policies page. 
Introduction for IM special section

\title{
Rethinking Transnationalism in the Global World: Contested State, Society, Border, and the People in between
}

\author{
Isabelle Cheng (University of Portsmouth) \\ Lara Momesso (University of Central Lancashire)
}

This special section presents three cutting-edge pieces of research on transnationalism from three interrelated perspectives: multifaceted identities, political participation, and micro-entrepreneurship. As elaborated by the five participating authors, these three perspectives converge on the critical role played by the state, which does not pale into socio-political insignificance because of the global movement of ideas, commodities, capital or people. Rather, standing steady against migration flows, with immigration legislation at hand as policy tools, the state is an 'agent of identity' that seeks to shape migrants' identity so as to preserve or advance its interests in domestic politics and foreign relations. In response, migrants are not passively susceptible to the state's manipulation. Instead, with the sociocultural capital accumulated throughout their migration, they critique, circumscribe or take advantage of the state legislation, whilst negotiating the ever-changing popular discourses that often reinforce their stigmatisation. As shown in this special section, migrants' performance of identity, political participation and microentrepreneurship give rise to a vista of everyday transnationalism where the host state and society interact with migrants, sandwiched in between in consequence of their border-crossing.

Taking their inbetweenness as our point of departure, we offer fresh theoretical and empirical insights to the transnational bonds forged across or within borders administered by the state. This malleable geographical and socio-economic transnational space is reined in by the intent of the state to regulate the transgression of labour, capital, culture, identity, intimacy and consumption. Whilst this transgression is inherent to globalisation, it also inadvertently manifests the endurance of sovereignty, the interference of partisan politics and nationalist interests, and the defiance and aspiration of migrants to autonomy and solidarity. 
These challenges and responses holistically attest the necessity of treating the state as well as individuals as equally important units of analysis so as to grapple with the dynamism arising from transnationalism.

Our insights as outlined above were obtained via our research on migration to and from Taiwan, specifically migrants from Southeast Asia and those crossing the Taiwan Strait to reside in China or Taiwan. Because of marriage or investment, their border-crossing makes Taiwan an illuminating case for re-thinking transnationalism as a theoretical framework in migration studies and everyday practice in migrants' lived experiences. On the one hand, Taiwan is a typical 'migration state' (Hollifield 2004) whose interests lie in liberalising the market, for the economic benefits rendered by migration, but at the same time in scrutinising the granting of membership of the national community for the sake of cohesion and stability. On the other hand, Taiwan is an 'exceptional state' (Friedman 2015) whose sovereignty is contested and which therefore has a vested interest in utilising its governance of migration to defy such contestation.

Our emphasis on exceptionality embodied by Taiwan's contested sovereignty corresponds to the concern with locality embedded in transnationalism. Sovereignty, citizenship and borders are modern creations revolving around the concept of locality, which seems to be crumbling due to increasing hybridity, flexibility, fluidity and in-betweenness (Bhabha 1990: 4). At the same time, transnationalism scholarship also asserts that restricting the identification of an individual, ethnic group or nation to a fixed location is insufficient to delineate the mobility that has become a constant, rather than a variable, in the social landscape (Schultermandl and Toplu 2010: 11-17). Earlier scholarship on transnationalism tended to prioritise individuals and focus on the social spheres emerging from their engagement with the global world (Glick-Schiller et al. 1992; Glick-Schiller et al. 1995; Guarnizo and Smith 2008; Portes et al. 1999; Vertovec 2009). They often celebrated the agency of migrants for their ability to determine their social universes. However, recent studies on the transgression of the 'walled state' (Brown 2014) have shed new light on the lingering influences of structural forces. They advocate the need to stress the 
emerging opportunities and constraints in the world system which 'foster, shape, [and] disable local agency' (Lazar 2011: 76). Echoing this call, our special section demonstrates how, under globalisation, the state and individual are in a constant struggle between the former's intent to scrutinise and homogenise migrant outsiders and the latter's endeavour to survive and assert their identity.

This constant struggle between the state and individual is best projected by our chosen case studies of migration to and from Taiwan in consequence of migrants' marriage and investment. This exceptionality in conjunction with the governance of marriage migration and investment illustrates the tug of war between the state's governing structures and migrants' agency. Employing the intersectionality of gender, class and ethnicity (Al-Ali and Pratt 2009; Higginbotham 1992; King 1988; Mohanty 2003), we do not treat the factors of structure and agency as entities of homogeneity but as a conglomeration of various interests sometimes conflicting with each other. Therefore, a theoretical contribution of this special section is to bring the state back into the glocalisation accentuated by state legislation and migrants' agency. As mentioned above, the study of transnationalism has been dominated by the arguments of the withering state, mobility and hybridity. However, our research on marriage migrants in Taiwan and Taiwanese expats in China shows that 'glocalisation' is not a homogeneous experience when the conditions, processes and consequences of migrants' border-crossing are subject to how their gender, class and ethnicity are regulated by the state and perceived by the society.

Another theoretical contribution made by this special section is our rejection of the rigid socio-legal and academic categorisation of migration experiences determined by immigrant status. In state legislation, migrants from Southeast Asia and China who enter Taiwan for marriage are designated respectively as Foreign Spouses (Waiji Peiou) and Mainland Spouses (Dalu Peiou). In everyday vernacular, they are abbreviated as 'Waipei' and 'Lupei', or 'New Residents' (Xin Zhumin) by the latest politically correct label. Those Taiwanese expats who enter China for investment are socio-legally known as Taiwanese Businesspeople (Taishang) with a predominantly male image. As transmigrants whose frequent border-crossing 
between Taiwan and China is essential for their business operation, these expats are not regarded by the Taiwanese and Chinese states as migrants per se but investors. After all, their profit-seeking activities in China are, by default, mobile and temporary. These categorisations of spouses and business owners erected by state legislation for the purpose of regulating their rights and entitlements also define the analytical categories used by scholarship. That is, migrant spouses' experiences are studied in the field of 'marriage migration', whereas Taiwanese expats' experiences are bracketed into the field of 'foreign direct investment'. As indicated by our research, Taiwanese expats in China were not seen as 'migrants' until significant changes of their life course took place, such as the relocation of their families to China, or their children attending either local schools or those schools exclusively enrolling Taiwanese students. As demonstrated by our findings, going beyond these conventional categories is critical for recognising migrants' agency in re-configuring their multifaceted identity derived from their negotiation of 'us-them' relations. Not being constrained by these categorisations has indeed enabled us to uncover common experiences shared amongst migrants, regardless of their physical locality, their socio-economic standing or their legal categorization.

Keeping in mind the exceptionality of the Taiwanese state and the mutual hostility between Taiwan and China, Cheng, Momesso and Fell explore everyday transnationalism in the realm of migrants' political participation. Treating political parties as an institution of the state, their research projects a dynamic picture in which the Democratic Progressive Party (DPP) and the Kuomintang (KMT), the two major political parties in Taiwan, sought to reach out to the immigrant constituency by publicising their election manifestos, establishing supporter groups, founding an immigrant-specific committee in the central party organisation, recruiting immigrant activists for election campaign, airing advertisements on TV and YouTube, communicating via Facebook for enhanced personal appeal, and, as the latest electioneering strategy, nominating immigrants for legislative and executive positions. The exceptionality of Taiwan is noted in their research into the DPP's attempt at using Southeast Asian spouses for advancing the implementation of the New Southbound Policy, whereas the Taiwan-China hostility is the context for the 
unequal eligibility for citizenship of Mainland Spouses and ignoring them in election publicity. In response to the two parties' politicisation of migrants' transnational ties, this research demonstrates that Southeast Asian activists grasped the newly opened political opportunities, including the representation granted to immigrant constituencies in political institutions, for social advocacy and cultural entrepreneurship, whilst maintaining their vigilance towards the DPP's Southbound Policy given its puzzling lack of concerns about migrant workers in Taiwan. Whilst the Southeast Asian spouses are granted representation, Cheng, Momesso and Fell show that, under disadvantageous circumstances, Chinese activists achieved selfrepresentation by establishing political parties and promoting Chinese nationalism as well as peace between Taiwan and China. These attempts are partly explained in the context of increasing political opportunities made available by the KMT presidency during 2008-2016, when a more moderate stance was adopted towards China. Partly it is also a consequence of China's reaching out to the Chinese community in Taiwan. On the whole, as stressed by Cheng, Momesso and Fell, these transnational ties sustained whilst Chinese community in Taiwan acknowledged that they were influenced by the indoctrination of Chinese nationalism implemented by the Chinese government. At the same time, Chinese spouses also showed their understanding of how the Taiwanese identity have grown in Taiwan.

The complexity of transnationalism in the realm of identity formation is the theme of the article of Momesso and Lee. Against the background of Taiwan's exceptionality and China's denial of Taiwan's sovereignty, Momesso and Lee demonstrate how both states became 'agents of identity' in their attempt to defeat the other's nation-building. By offering practical benefits, the Chinese government aimed at winning the hearts and minds of Taiwanese expats in China, whilst strengthening the transnational bonds with Chinese spouses in Taiwan. In defiance, ready to strike in punishment, the Taiwanese government kept a close eye on the expats in China for indications of their identity shifting, whilst differentiating Chinese spouses in Taiwan into an ambiguous and unfavourable legal status. Enticing Taiwanese expats into Chinese nationalism or securing their Taiwanese identity is the trophy in this game of carrot and stick. For Taiwanese expats in China, being the 
privileged other (Tseng and Wu 2011), they walked a thin line between enjoying the advantages offered by their host and avoiding the politicisation of their identity by both sides. For Chinese spouses in Taiwan, who could either positively act as a bridge over the socio-political chasm or passively view themselves as pawns sandwiched between the long-standing rivals (Cheng 2016), their expression of identity was contingent on the partisan politics of Taiwan, which either rendered or reduced political opportunities for their collective action. In spite of the contrasting resources available to Taiwanese expats and Chinese spouses for publicly performing their identity, the study of Momesso and Lee underlines that it is not researchers but migrants themselves who reiterated, but also overcame, the dichotomy between primordialist and instrumentalist approaches when ascertaining their identity.

Whilst the two articles outlined above examine everyday transnationalism in comparative perspective in the political sphere, our stress on transnationalism in everyday practice is most evident in Zani's biographical study of Chinese spouses' micro-entrepreneurship. Breaking the boundaries between the categories of labour migrants and marriage migrants, Zani's research on economic transnationalism shows how Chinese women's mobility not only took them from rural villages to urban cities but further, crossing the Taiwan Strait to reside in Taiwan as wives and mothers. Although gender may seem to have restricted their migration options to employment at factory and marriage as a means of mobility, gender also underlines their self-help solidarity and socio-cultural capital that holistically contributed to their running of e-commerce enabled by online technology. Zani's longitudinal approach shows that taking place alongside their employment, marriage and divorce, Chinese women's economic transnationalism thrived, embodied by their 'paolai paoqu' (going back and forth). The seemingly ambiguous and implicit 'here and there' identity, as argued by Zani, has become a new socio-economic status proudly maintained by the migrant entrepreneurs and noted enviously by their families, friends and customers.

On the whole, our research on migration to and from Taiwan and our stress on contested sovereignty, regulated borders and people in between have enriched our 
understanding of transnationalism as a policy tool and as a lifestyle. We underline the fact that when people migrate for marriage and investment between two states which are locked in a potential armed conflict and which boast mutually antagonistic national narratives, the migrants and their capital, as well as their private intimacy, fall prey to the state's political manoeuvring. Their acute awareness of their inbetweenness actively interacts with their multifaceted identities. Thus, as analysed by our research, from the top down transnationalism has become a policy tool for the states of Taiwan and China to reinforce their nation-building project. From the bottom up, transnationalism is a reality lived by migrants in their intimacy with family members, their ambiguous performance of identity, their choice of everyday products, their decisions in political participation and their micro-entrepreneurship thriving in the chat room on their mobile phones.

\section{References}

Al-Ali, N., and Pratt, N.

2009. Introduction. In: Al-Ali, N., and Pratt, N., eds. Women and War in the Middle East: Transnational Perspectives, pp. 1-31. New York: Zed Books.

Bhabha, H.K.

1990. Introduction: narrating the nation. In: Bhabha, H.K., ed. Nation and Narration, pp 1-7. London: Routledge.

Brown, W.

2010. Walled States, Waning Sovereignty. New York: Zone Books.

Cheng, I.

2016. Bridging across or sandwiched between? Political re-Socialisation of Chinese immigrant women in Taiwan. Asian Ethnicity, 17(3): 414-434.

\section{Friedman, S. L.}

2015. Exceptional States: Chinese Immigrants and Taiwanese Sovereignty. Berkeley, University of California Press.

Glick-Schiller, N., Basch, N., and Blanc-Szanton, C. 1992. Transnationalism: A new analytic framework for understanding migration. In: Glick-Schiller, N., Basch, N., and Blan-Szanton, C., eds. Towards a Transnational Perspective on Migration: Race, Class, Ethnicity, and Nationalism Reconsidered, pp. 1-24. New York: The New York Academy of Science.

Glick-Schiller, Nina, Basch, L., and Blanc-Szanton, C. 
1995. From immigrant to transmigrant: Theorizing transnational migration. Anthropological Quarterly, 68 (1): 48-63.

Guarnizo, L.E., and Smith, M.P.

2008. The location of transnationalism. In: Smith, M. P. and Guarnizo, L.E. eds.

Transnationalism from Below: Comparative Urban and Community Research, pp. 334. London: Transaction Publishers.

Higginbotham, E.B.

1992. African-American women's history and the metalanguage of race. Signs, 17(2): 251-274.

Hollifield, J. F.

2004. The emerging migration state. International migration review, 38(3), 885-912.

King, D.

1988. Multiple jeopardy, multiple consciousness: the context of black feminist ideology. Signs, 14(1): 42-72.

Lazar, A.

2011. Transnational migration studies. Reframing sociological imagination and research. Journal of Comparative Research in Anthropology and Sociology, 2 (2): 6983.

Mohanty, C.P.

2003. 'Under Western Eyes' revisited: Feminist solidarity through anticapitalist struggles. Signs, 28(2): 499-535.

Portes, A., Guarnizo, L.E., and Landolt, P.

1999. The study of transnationalism: Pitfalls and promise of an emergent research

field. Ethnic and Racial Studies, 22(2): 218-237.

Schultermandl, S., and Toplu, S.

2010. A fluid sense of self: the politics of transnational identity in Anglophone literatures. In: Schultermandl, S., and Toplu, S., eds. A Fluid Sense of Self, pp. 11-24. Münster: Lit Verlag.

Tseng, Y.F. and Jiehmin Wu.

2011. Reconfiguring citizenship and nationality: dual citizenship of Taiwanese migrants in China. Citizenship Studies, 15(2): 265-282.

Vertovec, S.

2009. Transnationalism. London: Routledge. 